\title{
Engaging with higher education back home: Experiences of African academic diaspora in the US
}

\author{
Ayenachew A. Woldegiyorgis \\ Boston College, USA \\ Email: ayenachew.woldegiyorgis@bc.edu \\ Address: Boston College, 140 Commonwealth Avenue, Chestnut Hill, MA 02467
}

\section{Introduction}

The phenomenon of continued outflow of highly educated individuals from developing countries, dubbed as 'brain drain', created winners and losers in the global competition for skilled manpower, and exacerbated the knowledge divide between rich and poor countries. Africa is among the regions seriously affected by such outflow of skilled citizens taking away the most talented from its limited pool of human capital. In response, as national governments and their development partners focus on initiatives of 'diaspora engagement' (Mangala 2017; Meyer et al 1997), specific types of diaspora - such as the academic diaspora - are receiving particular attention. Focusing on what Koser (2003) dubbed as 'the new African diaspora' - formed by immigration in the post-colonial Africa - academic diaspora is conceived as constituting specifically those in the academic career, which is in turn understood as a subset of the broader skilled, scientific or intellectual diaspora.

As Zeleza (2013, p. 4) noted, the African academic diaspora "constitutes the sharp edge of Africa's unusually high rates of skilled labor migration, the highest in the world for a region with the world's lowest stock of skilled workers". Meanwhile, African higher education institutions are positioned in the periphery of the global knowledge system (Goujon, Haller and Kmet 2017), among other things due to the constant outflow of qualified academics. Positive developments towards filling this gap, which come both from reform agendas within the continent as well as the increasingly shifting interest from the rest of the world (Singh 2011; Teferra 2010) are challenged by the realities of limited capacity.

This puts the African academic diaspora in a uniquely important position to not only mediate the relationship between Africa and the advanced higher education systems they belong to, towards bridging the center-periphery divide (Welch and Zhang 2008), but also to supplement the capacity gaps in the African higher education. The scholastic visibility and political capital of the academic diaspora is an indispensable resource (Teferra 2003) in the aspiration of African higher education to ascend in the global knowledge system. Diasporas also have much stronger leverage to raise resources for academic and research activities from western sources (Zeleza 2013).

\section{Framing the research methods}

In spite of the recognition for the importance of the engagement of African academic diaspora with institutions back home, there is very limited research examining what such engagements look like, what factors help their success, or what sort of dynamics and challenges they have to deal with. Employing phenomenological research methods (Moustakas 1994) in the broader sense, this study uses data from in-depth interviews to explore the transnational engagement of African born academics in US institutions, through their own experiences. Following Vagle's (2018) invitation for phenomenological researchers to build on, stretch, or draw from aspects of established approaches, this 
research considers other supplementary sources of data, including interviews with officials of universities in Africa, officials and experts form agencies responsible for diaspora engagement, leaders of diaspora organizations and networks, review of reports and other documents from concerned organizations and so on.

\section{Theoretical foundation}

Theoretically the research is informed by Bourdieu's (1977) Theory of Practice. The African academic diaspora are understood to operate in an environment of multiple and complex constituents which they have to engage and negotiate with. As academics of color, they have to work through the complex systemic and individual challenges of the racialized American academy. As immigrants, they have to make social adjustments while they face challenges of legal requirements, more so today than before. Meanwhile they have to find their positions in society through negotiating their relationships with the native-born American society as well as diasporas of different origins. As emigrants, they have to live with the straining demands from home, ranging from the more personal expectation for material and moral support to the more abstract burden of having to defend Africa (Zeleza 2004). Theory of Practice offers an integrative framework that connects the individual and the social, and the agential and the structural. With its broad view and through its elements - habitus, field and capital - theory of practice affords the space for a phenomenological inquiry into the complex multifactor experiences of the African academic diaspora in the US in their transnational engagement with higher education in Africa.

\section{Significance of the study}

The research unravels how African born academics in the US make sense of their engagement with institutions back home. Doing so it provides an understanding on a dimension of international higher education rarely discussed in the literature. It provides critical strategic input for both US and African institutions on how they can make use of the potential of the African academic diaspora in bridging their transnational partnerships, and more broadly in their internationalization and global engagement agendas.

\section{References}

Bourdieu, Pierre. 1977. Outline of a theory of practice (R. Nice, Trans.). Cambridge: Cambridge University Press. Goujon, Anne, Max Haller, and Bernadette Müller Kmet. 2017. Introduction to Higher Education in Africa: Challenges for Development, Mobility and Cooperation, viii-xv. Cambridge Scholars Publishing.

Koser, Khalid. 2003. "New African diasporas: an introduction." In New African Diasporas, edited by Khalid Koser, 21-36. Routledge.

Mangala, Jack. 2017. "Engaging diasporas in development: Contours and outcomes of international policymaking." In Africa and Its Global Diaspora: The Policy and Politics of Emigration, edited by Jack Mangala, 3-37. Cham: Springer.

Meyer, Jean-Baptiste, Jorge Charum, Dora Bernal, Jacques Gaillard, José Granés, John Leon, Alvaro Montenegro et al. 1997. "Turning brain drain into brain gain: the Colombian experience of the diaspora option." Science, technology and Society 2(2): 285-315.

Moustakas, Clark. 1994. Phenomenological research methods. Thousand Oaks, CA: Sage publications.

Singh, Mala. 2011. "Equity and quality in the revitalisation of African higher education: Trends and challenges." Research in Comparative and International Education 6(4): 348-365. 
Teferra, Damtew. 2003. "Unleashing the forces of the diaspora: Capitalizing on brain drain in the era of information and communication technologies." In Diasporas Scientifiques/Scientific Diasporas Part II, edited by Meyer, J. B., R. Barré, V. Hernandez, and D. Vinck, 226-243. Paris: IRD Editions.

Teferra, Damtew. 2010. "Deploying Africa's intellectual diaspora: Potentials, challenges and strategies." In Higher education and globalization: Challenges, threats and opportunities for Africa, edited by Damtew Teferra and $\mathrm{H}$. Grejin, 89-100. Maastricht: MUNDO.

Vagle, Mark. 2018. Crafting phenomenological research (2 $2^{\text {nd }}$ Ed.). New York and London: Routledge.

Welch, Anthony, and Zhang Zhen. 2008. "Higher education and global talent flows: Brain drain, overseas Chinese intellectuals, and diasporic knowledge networks." Higher Education Policy 21(4): 519-537.

Zeleza, Paul. 2004. "The African academic diaspora in the United States and Africa: The challenges of productive engagement." Comparative Studies of South Asia, Africa and the Middle East 24(1): 261-275.

Zeleza, Paul. 2013. Engagements between African diaspora academics in the US and Canada and African institutions of higher education: Perspectives from North America and Africa. New York: Carnegie Corporation of New York. 